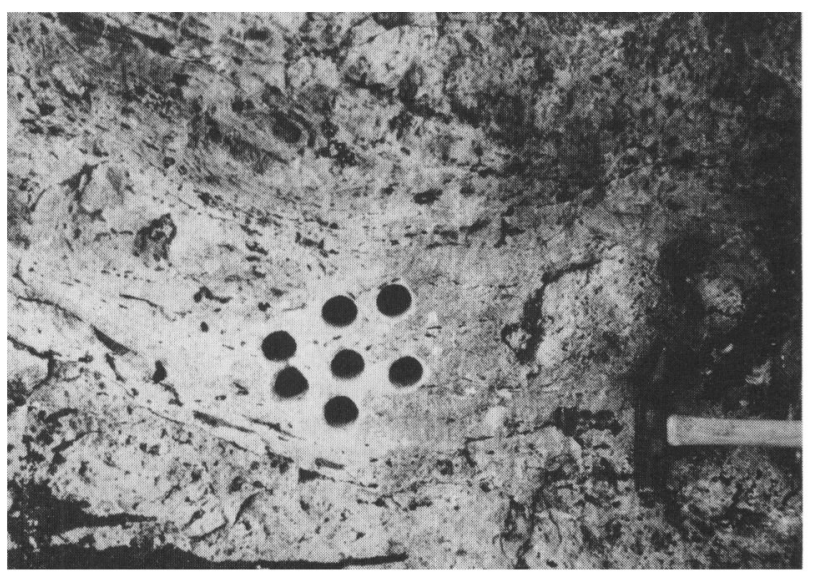

FIG. 2. Zechstein reef facies, Tunstall Hill, Sunderland, County Durham. Approx. half of handle of Geologist's hammer (below on right) gives scale. Photo: Dr Denys Smith.

For this reason it seems preferable not to conduct any individual witch-hunt but rather to ask everybody to support a self-regulatory Code of Conduct embodying the following principles:

1. Take cores from the least-exposed faces and avoid those which are most obviously visible on entering a quarry or approaching a natural exposure.
2. Take only the minimum number of cores necessary, and avoid closely-spaced patterns, which will attract undue attention.

3. As best you can, try to plug the holes with quarry debris of similar type and colour to the surrounding rock. Wherever possible, re-fill the holes with plugs of a slightly smaller diameter drilled from fallen blocks of the same material.

4. Have respect for the feelings of other geologists who may well, against their own natural instincts but out of regard for others, have already consented to a 'no hammering' limitation at the same locality.

It is clear from the literature of geology that careless rock-coring is a world-wide problem and one that is by no means confined to the British Isles. If we were to achieve wide-ranging support for such voluntary self-restraints. we could justly feel that we had scored a very significant success.

ERIC ROBINSON
G.A. Librarian \& Press Officer
Department of Geology
University College London
Gower Street
London WC1E $6 B T$
England, UK.

\title{
Success Against Shifting Sands in Uzbekistan
}

The article in Environmental Awareness (vol. 12, pp. 73-4, 1989), entitled 'Success Against Shifting Sands', by Monique Mainguet, describing the work of Sekkou Zouha in controlling moving sand-dunes in Morocco, reminded me of a comparable situation observed in 'Middle Asia' in 1975.

My observations were made on the excursion after the XII International Botanical Congress, Leningrad, 1975, to Uzbekistan, formerly Russian Turkestan. One of the field trips on this excursion was from the fabled city of Bukhara to beyond Shafrikan on the southeastern edge of the remarkable Kyzyl-Kum Desert, lying to the south-east of the Aral Sea. Here, moving dunes tend to encroach on the inhabited area of which Bukhara is the centre.

A short visit to the actual desert of huge, active, crescentshaped or 'barkan' dunes left a lasting impression, both of the majesty of these vast sands, and of the ingenious ways in which plants have adapted to life in this difficult 'habitat'. Most conspicuous were the umbelliferous Ferula asafoetida, monocarpic, with a large crown of horizontal fruiting branches at the top of a well-rooted, erect, thick, pithy, trunk-like stem, at the time of our visit dormant and leafless; Haloxylon aphyllum, a shrub with no leaves but thick green photosynthetic stems: Aristida karelinii, a large tightly-clumped grass with an extensive spreading root-system of horizontal roots radiating under the sand-surface to several metres in all directions; and Alhagi canescens, one of the 'camel-thorns', a rigid microphyllous to leafless shrub, and constituting one of the dominants in this sparse vegetation.

Out from Shafrikan was a wooded hill, topped by ruins of the Vardanzy Castle, a fortification of the ancient Tsars of Middle Asia, and more ancient even than Bukhara. From the base of this hill we walked through a forest of Haloxylon aphyllum, here reaching small-tree size, of the Chenopodiaceae-a family familiar to most of the party as herbaceous garden weeds. In the undergrowth were shrubs of Alhagi sp., Tamarix sp., Lycium muthenicum, a species of Zygophyllum, the Common Reed, Phragmites australis, and the herbaceous 'vine' Cynanchum sibiricum.

The flat top of the hill bore a different type of vegetation-semi-open, among stonework ruins. Here we were given a short talk by a botanist from the Bukhara branch of the Tashkent Botanical Institute. She explained that the area had been an important trade centre in the 19th Century, that it had been inhabited until the 1930s, and that the area we had been walking through had then been a town. The dunes had moved in from the desert and buried the town, so that the area we had been walking over was actually the site of the buried town. The forest is entirely artificial. In 1936 the Botanical Institute was instructed by the Government to undertake a project to stabilize the dunes - to stop their encroachment on the fertile agricultural Serafshan Valley.

This thoroughly natural-appearing chenopodiaceous forest is the result of their efforts, completely successful in 30 years, in stopping the advance of the dunes.

We were informed that we were the first foreigners to visit and see this achievement, which our Russian hosts were pleased to show us.

F. Raymond FosberG, Botanist Emeritus National Museum of Natural History

Smithsonian Institution

Washington

DC 20560, USA. 